Jurnal Administrasi Publik (Public Administration Journal), 10(2) December 2020

ISSN2088-527X (Print) ISSN2548-7787 (Online) DOI: https://doi.org/10.31289/iap.v10i2.3603

Jurnal Administrasi Publik

(Public Administration Journal)

Available online http://ojs.uma.ac.id/index.php/jap

\title{
Quality of Tour Driving License Services in Semarang Regency
}

\author{
Thirdy Hadmiarso* \& Kismartini \\ Public Administration Masters Study Program, Diponegoro University, Indonesia
}

Received: March 16, 2020; Reviewed: April 28, 2020; Accepted: May 05, 2020

*Coresponding Email: thirdy98@yahoo.co.id

\begin{abstract}
The Semarang Police, as a form of bureaucratic reform in services, uses a Tour Driver's Licenseservice. However, in its implementation, there are still many obstacles, namely inadequate infrastructure for Tour Driver's License services and lack of human resources. The purpose of this study was to analyze the service quality of a Tour Driver's License in Semarang Regency and the factors inhibiting and supporting it. This research uses a descriptive qualitative approach. The data analysis technique used is qualitative analysis (data condensation, data presentation and conclusion drawing). Based on the results of data analysis, it can be seen that the service quality of Tour Driver's Licenses in Semarang Regency is good. Service implementers have the ability and are able to act professionally. It's just that in its implementation it is constrained by a lack of infrastructure, namely there is only one Tour Driver's License unit, waiting chairs and tents are still not available, and a lack of human resources. There is a need for additional facilities, infrastructure and human resources to support the implementation of Tour Driver's License services so that they are able to reach all areas in Semarang Regency.
\end{abstract}

Keywords: Service Quality, Driver's License, Semarang Regency

How to Cite: Hadmiarso, T. \& Kismartini. (2020). Quality of Tour Driver's License Services in Semarang Regency. Jurnal Administrasi Publik (Public Administration Journal). 10(2): 174-183 


\section{INTRODUCTION}

The function of the police is contained in Law Number 2 of 2002 concerning the State Police of the Republic of Indonesia Article 2. The function of the police, namely the function of the state government in the field of maintaining security and public order, law enforcement, protection, protection and public services. One of the community services provided by the Indonesian National Police is the service for making and renewing driving licenses.

The Semarang District Police, to facilitate the service of driving licenses to the public, also uses a Tour Driver's License service. Tour Driver's License services, specifically driving licenses $\mathrm{A}$ and $\mathrm{C}$, are renewed, lost and damaged and services are carried out in locations that can be moved according to need. The existence of a Tour Driver's License service is intended to provide services in accordance with the needs of the community. The objectives of the self-driving license service are: 1) To provide services to people whose domicile is far from the Semarang Police's driving license service office; 2) To facilitate services to the community in the processing of a driving license extension, so that there are no more time and distance constraints for the people of Semarang Regency.

The application of a Tour Driver's License in Semarang Regency began on November 10, 2016, while the standard operating procedure for Tour Driver's License services has been in place since July 1,2015 . At the beginning of the application of a Tour Driver's License, there was only one mobile driver extension service user in Semarang Regency and can be seen in the following table data :

Table 1 Tour Driver's License service users in Semarang Regency 2016

\begin{tabular}{|c|c|c|c|c|}
\hline \multirow[t]{2}{*}{ No. } & \multirow[t]{2}{*}{$\begin{array}{l}\text { Tour Driver } \\
\text { License }\end{array}$} & \multicolumn{2}{|c|}{$\begin{array}{c}\text { Type and Category Driver's } \\
\text { license Extension }\end{array}$} & \multirow[t]{2}{*}{$\begin{array}{c}\text { Quantity Publishing Tour Driver } \\
\text { License }\end{array}$} \\
\hline & & A $\quad$ AU & $\mathrm{C}$ & \\
\hline 1. & January & & & \\
\hline 2. & February & & & \\
\hline 3. & March & & & \\
\hline 4. & April & & & \\
\hline 5. & May & & & \\
\hline 6. & June & & & \\
\hline 7. & July & & & \\
\hline 8. & Agust & & & \\
\hline 9. & Sept & & & \\
\hline 10. & October & & & \\
\hline 11. & Nov & & & \\
\hline 12. & Des & & & \\
\hline \multicolumn{2}{|l|}{ TO' } & & 1 & $\mathbf{1}$ \\
\hline
\end{tabular}

Source: Semarang Police

In the picture above, it can be seen that in 2016 there was only one Tour Driver's License user in Semarang Regency, namely in December there was one person who extended the driving license C.
Furthermore, in 2017 there was an increase in users of Tour Driver's License services but not significant. The increase can be seen in the following table: 
Thirdy Hadmiarso \& Kismartini, Service Quality of a Touring Driver's License in the District

Table 2. Users of Tour Driver's License services at Semarang Regency in 2017

\begin{tabular}{|c|c|c|c|c|}
\hline \multirow[t]{2}{*}{ No. } & \multirow[t]{2}{*}{$\begin{array}{l}\text { Tour Driver } \\
\text { License }\end{array}$} & \multicolumn{2}{|c|}{$\begin{array}{c}\text { Type and Category Driver's } \\
\text { license Extension }\end{array}$} & \multirow[t]{2}{*}{$\begin{array}{c}\text { Quantity Publishing Tour Driver } \\
\text { License }\end{array}$} \\
\hline & & $\mathrm{AU}$ & $\mathrm{C}$ & \\
\hline 1. & January & & & \\
\hline 2. & February & & & \\
\hline 3. & March & 31 & 150 & 181 \\
\hline 4. & April & & & \\
\hline 5. & May & & & \\
\hline 6. & June & & & \\
\hline 7. & July & & & \\
\hline 8. & Agust & & & \\
\hline 9. & Sept & & & \\
\hline 10. & October & & & \\
\hline 11. & Nov & & & \\
\hline 12. & Des & & & \\
\hline \multicolumn{2}{|l|}{ TO' } & 31 & 150 & 181 \\
\hline
\end{tabular}

Source: Semarang Police

In the table above, it can be seen that users of Tour Driver's License services in Semarang Regency have increased to 181 users, consisting of 150 extension of driving license $C$ and 31 driving license extensions. Furthermore, in 2018 it experienced a significant increase and can be seen in the following table for the use of the 2018 Tour Driver's License service:

Table 3 Users of Tour Driver's License services in Semarang Regency in 2018

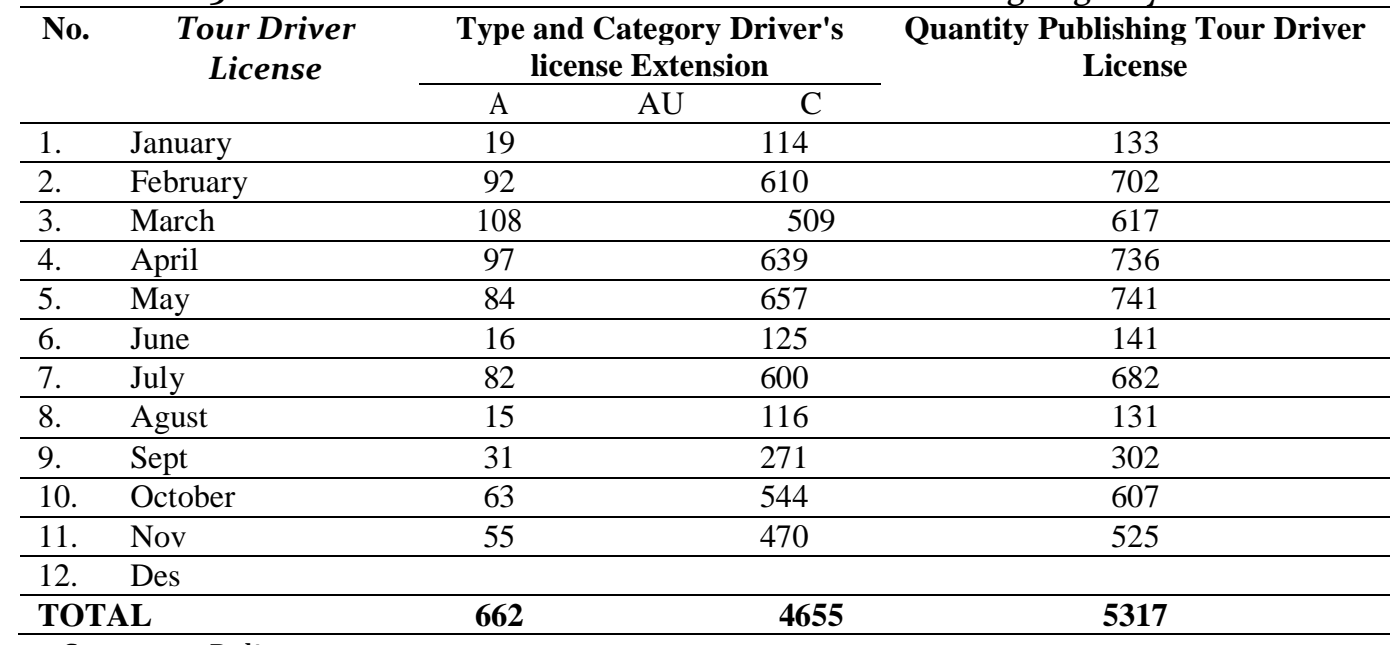

Source: Semarang Police

It can be seen in the table above, that users of Tour Driver's License services in Semarang Regency have greatly increased compared to the previous year, to 5317 service users consisting of 662 renewals of driving license A and 4655 renewals of driving license $\mathrm{C}$.

Public service basically aims to satisfy the community by providing excellent service satisfaction from the organizers (Diansari, 2017). This means that the best servants must be supported by means. The only one Tour Driver's License service car owned by the Semarang Police must be able to reach the Semarang Regency area which has an area of $946.86 \mathrm{~km} 2$. Another problem, as stated in Semarang Regency in numbers, is that as many as 513,987 people work and only have free time in the afternoon or evening after work. This has an impact on the use of the driving license service in Semarang Regency which is only effective at night, while the car that can be used for the service of a Tour Driver's License is only one unit and the large area of Semarang Regency cannot be reached 
entirely. There is only one human resource available to carry out services.

This research was conducted because there are still many obstacles in the Tour Driver's License service in Semarang Regency, namely the infrastructure for the Tour Driver's License service, which only has one unit of car and must reach all areas of Semarang Regency. Lack of human resources also hampers services because services are canceled when officers receive orders to carry out outside services. Services are also canceled if medical officers or officers who receive payments for Non-Tax State Revenue are unable to attend. According to Widodo (2001), the implementation of professional public services must have service standards and be published to provide assurance of certainty for service recipients (Sari, 2018). This means that the provider must complete the various facilities required. Service providers must understand the customer or make every effort to find out customer needs (Pratama, 2015).

Previous studies on the service quality of Tour Driver's Licenses. For example, Putra Laksana Putra (2016), who found that the Tour Driver's License service in Samarinda City is running well, although officers and suggestions need to increase the number. Then Bahrul (2015) saw the Electronic Service One-Stop One-Stop Administration System at the Manyar Kertoarjo East Surabaya One-Stop Administration System Office, with the results of using technology to simplify service and improve service quality, even though it was still constrained by the lack of information from the public. Research, Suryawan (2015), which aims to determine the quality of service for the extension of the Class C driving license at the Denpasar City Police found that the quality of service needs to be improved according to the expectations of the applicant / community. Basically, quality services depend on the pattern of implementation (governance), human resource support, and institutions
(Narita et al., 2016), so it requires support from various parties.

Based on the background of the problem, it can be seen that there are several problems in the implementation of Tour Driver's License services in Semarang Regency, such as: The quantity of human resources and facilities has not supported the service of a Tour Driver's License in Semarang Regency, there are other problems, namely the Semarang Regency area which has an area of $946.86 \mathrm{~km} 2$ and only 1 (one) unit of Tour Driver's License is available resulting in inaccessibility of all areas in Semarang Regency, and service implementation is often eliminated because only one implementer gets orders to carry out external services.

\section{RESEARCH METHODS}

The qualitative research process involves important endeavors, such as asking questions and procedures, gathering specific data from participants, analyzing data inductively from specific themes to general themes, and interpreting the meaning of the data. The main final report of this research has a flexible structure or framework (Ahmad, 2015).

This research is descriptive, which is a method of fact finding the status of a group of people, objects, conditions, a system of thought or an event in the present with the correct interpretation (Sedarmayanti \& Hidayat, 2011). The location of this research was conducted at the Semarang District Police. Sources of data in this study came from interviews with informants consisting of Assistant Commissioner of Police Sandhy Wiedyanoe, SIK Head of the Semarang Police Traffic Unit, First Police Inspector Adji Budi, Semarang Police Traffic Registration and Identity Unit, Brigadier Agus Jati N, field executor. Tour Driver's License service for the Semarang Police and Wahyu B and Sartono, a Tour Driver's License service user in Semarang Regency. 
This research focuses on the service quality of Tour Driver's Licenses in Semarang Regency, as well as inhibiting and supporting factors in the implementation of Tour Driver's License services in Semarang Regency. To see the quality of service using the theory of Parasuraman, et ... al, mentioning the main dimensions of service quality . First, reliability related to the company's ability to provide services. Second, responsiveness with regard to the willingness and ability of Human Resources to provide services. The third guarantee, namely the behavior of employees is able to foster customer trust. Fourth, empathy means that the company understands the problems of its customers. Fifth, physical evidence, regarding the attractiveness of physical facilities (Roro \& Nurdianti, 2018).

\section{RESULTS AND DISCUSSION} Analysis of Service Quality for a Driving License Rehabilitation.

The implementation of Tour Driver's License services in Semarang Regency is in accordance with service standards. Service time is also carried out from morning to evening, from 09.00 to 20.00 , with a quick process in each arrangement. Administrative services in the form of renewal of driving licenses and professional officers.

"The service time itself is effective because it starts from 9 am to $8 \mathrm{pm}$. The target service is carried out at night for workers who come home from work, " (Source: Interview Assistant Commissioner of Police Sandhy Wiedyanoe).

The timing is considered effective, because it adapts to community activities. "The timing was very effective, the ministry until the night was effective," (Source: Interview with Wahyu B, service users).

Fast process with easy process and service time adjusted to community conditions is very effective.
"The form of service with this Tour Driver's License, service is fast and easy." (source: interview Wahyu B, service users)

Responsiveness, Implementers of Tour Driver's License services in Semarang Regency have received socialization and technical guidance. The executor has the ability to solve problems faced in a professional manner, so as to provide the best service.

"Socialization must have occurred at the beginning of the service plan using a Tour Driver's License, it is certain that the officer appointed as the executor is given the ability and explanation of the service procedure to be carried out." (Source: Interview Assistant Commissioner of Police Sandhy Wiedyanoe)

The good ability of the officers is considered to provide a sense of comfort for the community in the process of extending their driving license. This is disclosed by service users.

"The executor provides his services according to the procedure, the service is also fast, so it is certain that he really understands the procedure." (Source: Interview with Sartono, a service user)

Guarantee, efforts to provide service guarantees are carried out in the form of disclosure of information regarding information regarding Tour Driver's License services which is socialized through mass media and the internet. The Semarang Police has also attached service schedules and service locations to the Tour Driver's License service units so that they are easily read and known by the public. The form of service guarantee is shown by the attitude of trained officers by prioritizing humanist and professional officers.

"Implementers have been directed to always be Humanist, Professional and prioritize services in accordance with Standard Operating Procedures." (Source: interview with First Police Inspector Adji Budi). 
Implementers are professional, trained and skilled in carrying out their roles, so that services can be carried out quickly and smoothly. The attitude of the implementers who are polite and friendly, in providing services has been felt by the service user community.

"I am happy that the executors are very friendly and carry out their duties very well." (source: interview of service user Sartono).

Empathy, empathy is giving personal attention to customers and trying to understand consumers. The empathy seen in the service process can be seen from the form of communication, because it will create a sense of comfort. Another form of empathy can be seen from the service process of providing the same service. The entire community has the right to get the same service from the executor.

"We serve Tour Driver's License users according to the serial number and in accordance with the existing Standard Operating Procedures, I myself do not discriminate in performing services." (source: interview with First Police Inspector Adji Budi)

Service in the field is implemented in the form of a queue number, and the implementer performs services based on that serial number. So that no community takes precedence, all get the same service according to the queue number obtained. This was disclosed by Sunarto as a service user

"Servants provide the same service, no one is differentiated, so they feel they have the same rights." (source: interview service user Sartono).

Physical Evidence, the facilities and infrastructure needed to provide Tour Driver's License services, namely Tour Driver's License car units and their equipment, tents, tables and chairs for medical services and payment of non-tax state revenue. These facilities and infrastructure are standard facilities that must be in the service of a Tour Driver's
License. In fact, the facilities and infrastructure currently available still do not support the wide range of Tour Driver's License services.

"The coverage area of Semarang Regency is very wide, so we need more than 1 car, but until now there have been no additions." (Source: Interview with First Police Inspector Adji Budi).

Apart from the problem with the Tour Driver's License service fleet unit, there are still no waiting seats, and only one service car unit is available, which hinders technical operators from providing the best service. Wahyu B felt this, a service user.

"I don't think so, because there is only one Tour Driver's License, no waiting chair." (source: interview Wahyu B service user)

\section{Analysis of Inhibiting and Supporting Factors for Tour Driver's License services in Semarang Regency}

Tour Driver's License facility provider, running a Tour Driver's License program with very wide field conditions and limited equipment, such as car units, computers, and the absence of waiting tents is a challenge for field officers to provide the best service. As a result, the services provided are very limited. This was revealed by the informant on duty in the field, that the support of the facilities is very decisive in providing the best service.

"Not enough. Service activities only use one car unit to reach the very wide area of Semarang Regency." (Source: Interview Assistant Commissioner of Police Sandhy Wiedyanoe)

The vast area of Semarang Regency also hinders officers from reaching the community to apply for a driving license with limited equipment, according to the public still lacking facilities.

"It doesn't seem like enough. Judging from the service car unit, he said there was only one." (source: interview service user Sartono). 
The impact of a large area with limited facilities is a problem for the police to provide the best service. Nevertheless, maximum efforts are continuously being made to reach people who are limited in time so that it is difficult to obtain a driving license from the office. Solutions such as the police continue to strive to expand their reach. The follow-up was carried out by the Semarang Police, namely making a letter requesting supporting facilities to the Police of the Republic of Indonesia. But still not getting an answer.

Human Resource Development, the availability of human resources in the Tour Driver's License service is still insufficient. The number of human resources provided by pure officers is only one police officer, medical staff and one person receiving payments from BRI Bank. Availability of Human Resources has a main function in providing services.

"The available human resources are only one executor, one medical person, one recipient of payment for non-tax state revenue" (source: interview First Police Inspector Adji Budi

The limited number of human resources in the field does not reduce skills. Placement of officers based on the ability and expertise in their field with knowledge of the basics of public services and standard operating procedures for Tour Driver's License services.

"Service provider officers have the appropriate abilities in their respective fields" (Source: Interview Assistant Commissioner of Police Sandhy Wiedyanoe).

Service users also feel the limited number of officers in the field which has an impact on the implementation of hampered activities.

"I think it's still lacking, because sometimes there are services, sometimes not, and certainly because there are no human resources." (source: interview service user Sartono).

\section{Work Climate and Work Relationship Harmony.}

The relationship between executors in the implementation of Tour Driver's License services in Semarang Regency is very good. Each of the executors, officers from the Semarang Police, medical officers and non-tax state revenue payment officers carry out their respective duties very well and are in good touch with each other to maintain the smooth process of driving a Tour Driver's License service in Semarang Regency.

"The relationship between the implementers is very good in accordance with their respective main tasks and functions." (Source: Interview Assistant Commissioner of Police Sandhy Wiedyanoe).

Relations between implementers have a good impact in providing services to the community. One of the efforts to build this relationship is coordination in the form of direct communication.

"The executors communicate directly because the service process is interconnected so that there is always good communication and coordination." (source: interview First Police Inspector Adji Budi).

Incentive Pattern, according to Mangkunegara (2011) Work incentive is an award in the form of money that is given by organizational leaders to employees so that they work with high motivation and achievement in achieving organizational goals. However, the implementer of the Tour Driver's License service in Semarang Regency has never received incentives from the start of the implementation until now.

"There is no incentive for officers because no budget is used as an incentive. Instead, we have to pay for freelance workers because of a lack of human resources." (Source: Interview Assistant Commissioner of Police Sandhy Wiedyanoe).

The non-existent budget is the cause of the absence of leadership incentives for 
implementing officers. The executor only gets a monthly salary.

Service patterns and procedures for providing services. There is a standard Tour Driver's License service in Semarang Regency which has been adapted to the demands of the community for fast and easy public services. In the Standard Operating Procedure, it is written the service schedule for the Tour Driver's License and the location of the service has been adjusted to the location of the area and daily lives of the people of Semarang Regency..

"Legal Basis and Standard Operating Procedures have been adapted to the demands of the community and are indeed arranged to make it easier for the community." (Source: Interview Assistant Commissioner of Police Sandhy Wiedyanoe)

In the implementation itself, it is in accordance with all applicable rules or legal bases to be able to reach all areas of Semarang Regency. The service itself is adjusted to the latest developments with the help of technology that makes it easier for officers and the community.

"It is appropriate and running to meet the demands of society in this modernization era. So people can get fast and easy service." (Source: Interview with Brigadier Agus Jati N)

The positive impact that can be felt with this implementation can be seen from experiencing the easy and fast service.

"It is very fulfilling. I feel satisfied with this service." (source: Revelation interview service users).

Service Distribution Service Patterns. Service distribution service patterns, namely the pattern of service delivery carried out by the Semarang Police to the public. Distribution procedures by selecting a location and time that are considered strategic and reaching all communities. However, a change in the implementation schedule that changes and does not create a feeling of discomfort for the community who will take care of it.

"It's good, usually the Tour Driver's License service moves places according to schedule so it can reach everything. But sometimes there is no service because officers have other tasks." (source: Revelation interview service users).

The limited number of officers is one of the reasons for the distribution schedule being held. The location selection has been determined based on field conditions starting from the community schedule, access and time.

Service Patterns in Service Delivery. Delivery of services carried out by operators of traveling driving licenses in Semarang Regency, namely according to schedule. Technically, the service schedule has been socialized affixed to the Tour Driver's License service car. The location and time are always adjusted and if there is a change, it is directly communicated to the public which is disseminated in electronic media that can be downloaded by the public.

"The location and time of service change and change according to the schedule that has been notified to the public through print and electronic media." (Source: interview of First Police Inspector, Adji).

The District Police of Semarang Regency continues to strive to provide the best service and continues to improve the quality of service so that the Tour Driver's License program can be reached by all people who have limited time. Good service and fulfilling the needs of public service users is an important element in realizing customer satisfaction (Customer satisfaction), (Rinaldi, 2012). One of the ways is by improving facilities and human resources to ensure that people get the best service.

\section{CONCLUSION}

The quality of Tour Driver's License services in Semarang Regency looks good 
based on Standard Operating Procedures starting from determining the location, schedule and time. Implementers are very skilled and responsible in providing services, always maintain communication with the community, do not discriminate, and are able to solve problems professionally and humanists. Information disclosure is a means of viewing schedules and locations. However, the available facilities and infrastructure still do not support the service of a Tour Driver's License, so that it becomes a barrier to service quality that continues to increase with a wide work range.

Inhibiting Factors for Tour Driver's License Services in Semarang Regency. Limitations, facilities and Human Resources become obstacles. The inhibiting factor is that the facility does not yet support Tour Driver's License services. Regarding human resources that are not sufficient, there is only one officer from the Semarang Police who if he gets an order or assignment from outside the leadership, then the Tour Driver's License service will be canceled. The last inhibiting factor is the incentive pattern. There is no budget for providing incentives. The executor only gets a salary which is due.

Supporting factors regarding the quality of service. First, there is a working climate and a good working relationship harmony with communication and coordination between services and the community. Car Driving License service distribution design looks good which is supported by the service pattern in the delivery of services according to the schedule. Field implementers are selected based on professionalism shown by skill and equipped with knowledge of providing services.

\section{BIBLIOGRAPHY}

Ahmad, J. (2015). Metode penelitian Administrasi Publik Teori \& Aplikasi. Gava Media, Yogyakarta.
AS, A. N., Warijo, \& Supriyadi, A. (2016). Analisis Kualitas Pelayanan Pada Kantor Dinas Pendapatan Provinsi Sumatera Utara UPT Medan Selatan. Jurnal Administrasi Publik (Public Administration Journal), 6(25), 87-96.

Bahrul, U. (2015). Kualitas Pelayanan Eletronic Samsat Pada Kantor Sistem Manunggal Satu Atap (SAMSAT) Manyar Kertoarjo Surabaya Timur. Publika., 01, 1-12.

Diansari, M. (2017). Analisis Kualitas Pelayanan Surat Ijin Mengemudi Kendaraan Motor (SIM C) di Polres Semarang 2016. EJurnal3.Undip.Ac.Id, Sim C, 1-14. https://media.neliti.com/media/publication s/90389-ID-analisis-kualitas-pelayanansurat-ijin-m.pdf.

Mangkunegara, AA.A.P. (2011). Evaluasi Kinerja Sumber Daya Menusia.

Peraturan Kepala Kepolisian Republik Indonesia Nomor 9 Tahun 2012. tentang Surat Izin Mengemudi

Pratama, M.H. (2015). Strategi Meningkatkan Kualitas Pelayanan Publik (Studi Deskriptif tentang Strategi UPTD Pengujian Kendaraan Bermotor Tandes Kota Surabaya dalam Meningkatkan Kualitas Pelayanan Pengujian Kendaraan Bermotor). Jurnal Kebijakan Dan Manajemen Publik, 3(3), 90-98.

Putra, R.L. (2016). Studi tentang pelayanan SIM Keliling di Satuan Lalulintas Kota Samarinda. E-Jurnal Pemerintahan Integratif, 4(1): 127.

Roro, R., \& Nurdianti, S. (2018). Penggunaan Metode Servqual dalam Pengukuran Kualitas Layanan Pendidikan. Indonesian Journal of Primary Education, 2(2): 71-75.

Rinaldi, R. (2012). Analisis Kualitas Pelayanan Publik. Publikauma: Jurnal Administrasi Publik UMA, 1(1), 37-39.

Roro, R., \& Nurdianti, S. (2018). Penggunaan Metode Servqual dalam Pengukuran Kualitas Layanan Pendidikan. Indonesian Journal of Primary Education, 2(2): 71-75.

Sari, W.H. (2018). Pelayanan Surat Izin Mengemudi (SIM) Oleh Polresta Pekanbaru (Studi kasus SIM Keliling. Jurnal JOM UNRI, 5(3), 113.https://doi.org/10.1017/CB0978110741 5324.004 .

Sedarmayanti \& Hidayat, S. (2011). Metodologi Penelitian. Mandar Maju: Bandung.

Suryawan, D.K. (2015). Kualitas Pelayanan Perpanjangan Surat Izin Mengemudi (SIM) Golongan C. Majalan Ilmiah "Dian Ilmu,"15(1): 58-74.

Undang-Undang R.I Nomor 22 tahun 2009. Lalu Lintas dan Angkutan Jalan 